\title{
Bond Strength of Basalt Based Glass-Ceramic Coatings
}

\author{
G. BAYRAK ${ }^{a, *}$, E. ERCENK ${ }^{b}, \mathrm{U} \mathrm{SEN}^{b}$ AND S. YILMAZ ${ }^{b}$ \\ ${ }^{a}$ Sakarya University, Department of Welding Technology, Arifiye Vocational High School \\ 54580 Arifiye, Sakarya, Turkey \\ ${ }^{b}$ Sakarya University, Engineering Faculty, Department of Metallurgical and Materials Engineering \\ Esentepe Campus, 54187 Sakarya, Turkey
}

\begin{abstract}
In the present study, powders produced from the volcanic basalt rocks were coated on pre-coated AISI 1040 steel with $\mathrm{Ni}-5 \%$ Al bond coat by atmospheric plasma spray coating technique. The coated specimens were characterized by optical microscopy, scanning electron microscopy, metallography and X-ray diffraction. Bonding strength of coatings was evaluated in accordance with the ASTM C-633 method. Coated basalt material from the APS coating system was determined in the glassy amorphous state by X-ray diffraction analysis. The coated samples were heat-treated at $800^{\circ} \mathrm{C}$ for $1-4 \mathrm{~h}$ for crystallization. The phases formed in the basalt base glass-ceramic coatings were augite, Fe-diopside, anorthite, and andesine which were detected by X-ray diffraction analysis. Basalt based glass-ceramic coatings include splat, porosity and un-melted particles which were the characteristic of plasma sprayed coatings. Experiment result showed that the crystallization time increase caused the decrease of the bond strengths of the coatings.
\end{abstract}

DOI: 10.12693 /APhysPolA.125.620

PACS: 61.43.Fs, 62.20.-x, 61.05.cp

\section{Introduction}

Thermal spray processes are available to deposit thick coatings for a broad range of applications. The processes are based on similar in that a material is heated up by a gaseous medium and simultaneously accelerated and projected onto the substrate. The family of thermal spray processes includes flame spraying, plasma spraying, vacuum plasma spraying (also called low pressure plasma spraying), high velocity oxygen fuel, arc metallization, and detonation gun spraying [1]. Plasma-spraying technique is currently the primary method used commercially to produce ceramic coatings [2].

Glass-ceramics are polycrystalline solids prepared by the controlled crystallization of glasses. Controlled crystallization usually involves a two-stage heat treatment process, namely a nucleation stage and crystallization stage. Glass-ceramic materials have superior properties in comparison with the traditional ceramics and glasses, which make them favorable for wear and corrosion resistant applications in advanced technology as well as in electronics and medicine. Basalt is a gray to black, fine grained volcanic rock. Superior abrasion, wear and chemical resistant basalt-based glass-ceramics can be produced from the basalt and they can be used for the transporting mechanical or chemical abrasive materials as well as noise and fire insulation, etc. [3-8].

Bond coatings are used widely in many industrial plasma-spray applications. They have specific functions; because the substrate and the main coating have different coefficients of thermal expansion, bond coating layer

*corresponding author; e-mail: gunhanb@sakarya.edu.tr should be used to provide a good thermal expansion match between these two different layers. Bond coatings are always thinner than the main coatings [2].

The aim of this study was to find out the effect of bond coat application on bond strength and microstructural characteristic of basalt based glass-ceramic coatings on AISI 1040 steel. The coatings were characterized by X-ray diffraction (XRD), optical microscopy and scanning electron microscopy (SEM). Bonding strength of coatings was tested using adhesion test ASTM C-633.

\section{Experimental procedure}

AISI 1040 steel samples to be coated were machined to the dimensions of $20 \mathrm{~mm}$ in diameter and $5 \mathrm{~mm}$ in height, and prepared metallographically by polishing with 1000 grit emery paper at the final stage. These samples were sand blasted with 35 grid alumina and cleaned ultrasonically in an ethyl alcohol and acetone for $15 \mathrm{~min}$ and dried. Basalt rocks were obtained as chunks and crashing was carried out in a jaw and cone crushers. Then, it was milled using ring miller and sieved to the grids of between 53 and $45 \mu \mathrm{m}$ for plasma spray coating.

The basalt based coating was produced using an APS technique on AISI 1040 steel with bond coating. $\mathrm{Ni}-5$ wt\% Al (METCO 450 NS) was used for the bond layer. The chemical compositions of volcanic basalt rock used for plasma spray coating treatment and the plasma-spraying parameters are given in Tables I and II, respectively (LOI $=$ loss on ignition).

Crystallization treatment was performed at $800^{\circ} \mathrm{C}$ for 1-4 $\mathrm{h}$ to promote internal crystallization in the argon atmosphere in a Lenton tube furnace. After deposition, glass without heat treatment process as coated and glass-ceramics coating samples were glued to pull rods 


\section{TABLE I}

Chemical analysis basalt rock used coatings (wt\%).

\begin{tabular}{c|c}
\hline \hline Compound & wt\% \\
\hline $\mathrm{SiO}_{2}$ & 45.88 \\
$\mathrm{Al}_{2} \mathrm{O}_{3}$ & 18.20 \\
$\mathrm{Fe}_{2} \mathrm{O}_{3}$ & 9.95 \\
$\mathrm{CaO}$ & 9.28 \\
$\mathrm{MgO}$ & 6.62 \\
$\mathrm{~K}_{2} \mathrm{O}$ & 1.64 \\
$\mathrm{Na}_{2} \mathrm{O}$ & 4.76 \\
$\mathrm{P}_{2} \mathrm{O}_{5}$ & 1.04 \\
$\mathrm{LOI}$ & 2.63
\end{tabular}

TABLE II

Plasma spray coating parameters.

\begin{tabular}{c|c}
\hline \hline Coating parameter & Value \\
\hline flow rate for argon $[1 / \mathrm{min}]$ & 50 \\
flow rate for hydrogen $[1 / \mathrm{min}]$ & 15 \\
current $[\mathrm{A}]$ & 500 \\
voltage $[\mathrm{V}]$ & $64-70$ \\
plasma gun type & METCO $3 \mathrm{MB}$ \\
spraying distance $[\mathrm{mm}]$ & 130 \\
powder feed rate $[\mathrm{g} / \mathrm{min}]$ & 39 \\
powder carrier gas $[1 / \mathrm{min}]$ & $3-6$
\end{tabular}

with an epoxy adhesive (cured for $24 \mathrm{~h}$ at ambient temperature) to determine the bond strength of coatings that is measured by means of a tensile machine with a crosshead speed of $0.5 \mathrm{~mm} / \mathrm{min}^{-1}$ according to ASTM C-633 method. Pull rods were also glued directly together in order to test the strength of the epoxy. Four samples were used in each group.

XRD was conducted with a Rigaku-type difractometer to analyze glassy amorphous state before crystallization and phases present in the coatings after crystallization. Optical microscope (Olympus BHM 313 U) and JEOL 6060 SEM were used to study the microstructure.

\section{Results and discussion}

Evaluation of the microstructures revealed that coating with bond coating has three different regions which are ceramic layer, bond coating, and matrix which are not affected by coating (Fig. 1). In general, plasma-sprayed layers include porosity, splat and un-melted particles.

The thickness of bond coat and basalt-based glass coating layer was measured by optical microscopy as 70 and $210 \mu \mathrm{m}$, respectively. XRD analyses of basalt based glass and glass-ceramics coatings were given in Fig. 2a and b. As seen, the figure basalt based as-coated coating was amorphous state. The phases identified in the basalt based coating subjected to controlled crystallization heat treatment are: augite $\left[(\mathrm{CaFeMg}) \mathrm{SiO}_{3}\right]$, Fe-diopside $\left[\mathrm{Ca}_{0.991}\left(\mathrm{Mg}_{0.641} \mathrm{Fe}_{0.342}\right)\left(\mathrm{Si}_{1.6} \mathrm{Fe}_{0.417}\right) \mathrm{O}_{6}\right]$, anorthite $\left[\mathrm{Ca}\left(\mathrm{Al}_{2} \mathrm{Si}_{2} \mathrm{O}_{8}\right)\right]$, andesine $\left[\left(\mathrm{Ca}_{0.38} \mathrm{Na}_{0.62}\right)\left(\mathrm{Al}_{1.38} \mathrm{Si}_{2.62} \mathrm{O}_{8}\right)\right]$.

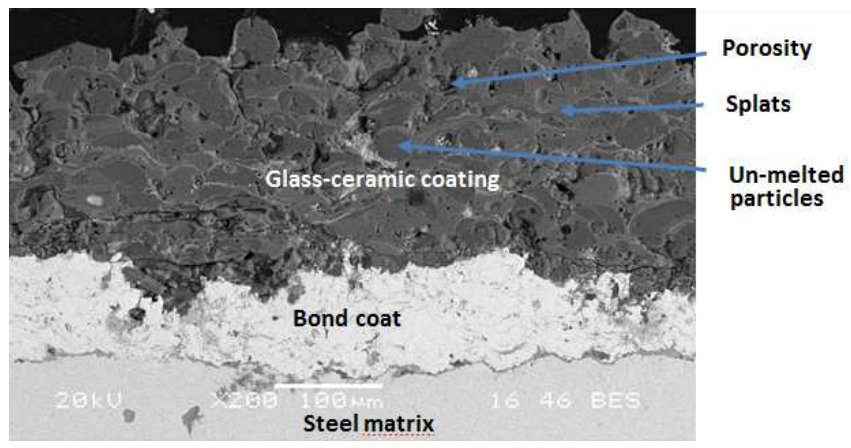

Fig. 1. SEM microstructure of the basalt based glass-ceramic.
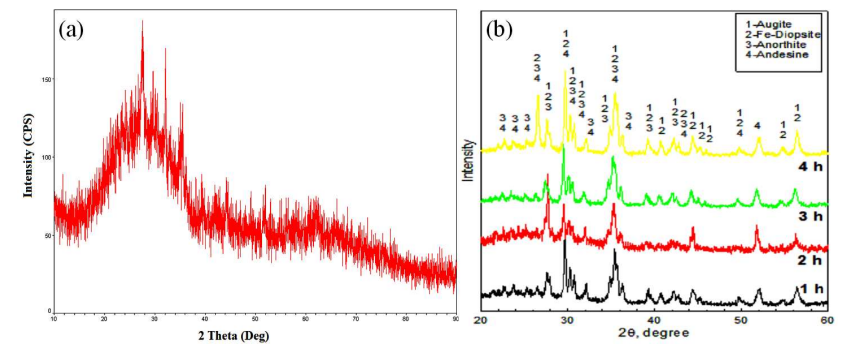

Fig. 2. (a) XRD pattern of the basalt based as-coated coating, (b) XRD pattern of the basalt based glass-ceramic coating at $800^{\circ} \mathrm{C}$ crystallization heat treatment.

The bonding strength of coating is a mix of cohesive and adhesive strength. As a bonding type, cohesive strength is called the remaining in the sample's surface. Adhesive strength is called removing from the sample's surface. The amount of coating remaining on the surface increases, and the cohesive strength of adhesion samples percentage increases [2]. The macrograph of basalt based coatings at $800{ }^{\circ} \mathrm{C}$ crystallization heat treatment after adhesion test and microstructure from adhesion test surface were given in Figs. 3 and 4, respectively.

As seen in the macrograph (Fig. 3), the coating subjected to crystallization heat treatment for $1 \mathrm{~h}$, the rupture realized from partially adhesive and from the partially coating surface. The rupture occurred from coating surface but some part of coating remained in $2 \mathrm{~h}$ heat treated sample. Similarly, after bond strength when a little part of coating remained in $3 \mathrm{~h}$ treated sample and rupture happened from coating surface, the rupture realized completely from coating the surface in $3 \mathrm{~h}$ heat treated sample. SEM micrograph was given in Fig. 4. There are three regions of the basalt based coating as glass-ceramic coating, fracture surface, and $\mathrm{Ni}-\mathrm{Al}$ bond coat.

Bonding strengths depending on heat treatment time of the basalt based coatings were given in Fig. 5. As 


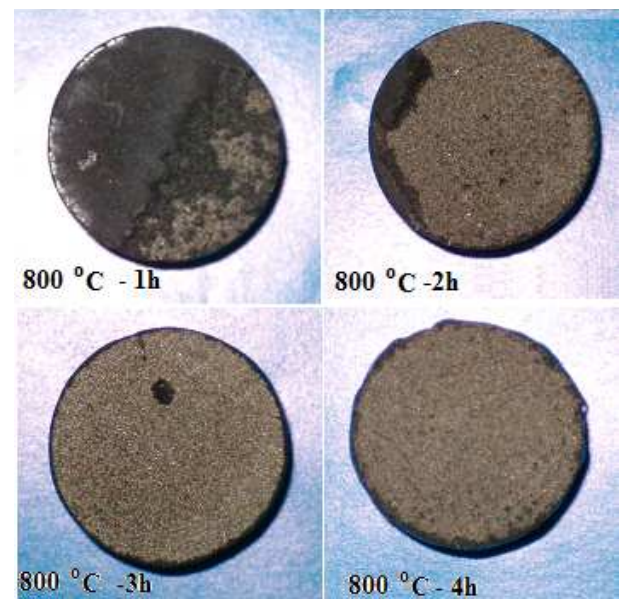

Fig. 3. The macrograph of basalt based coatings at $800^{\circ} \mathrm{C}$ crystallization heat treatment after adhesion test.

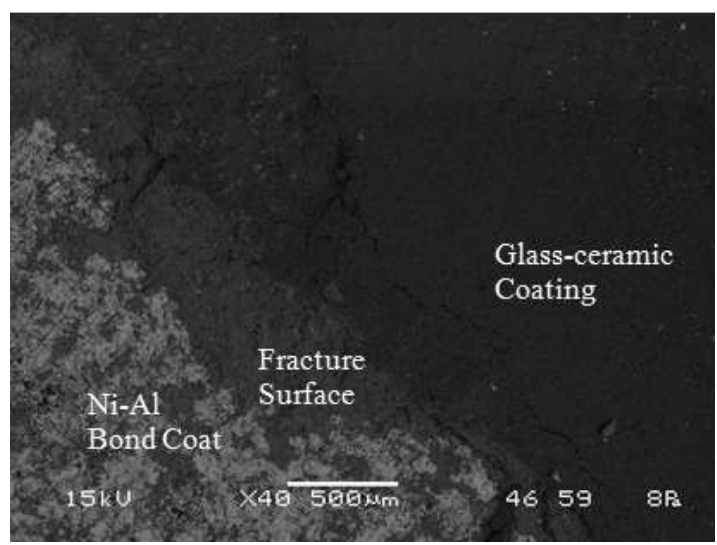

Fig. 4. SEM microstructure from adhesion test surface of heat treated at $800^{\circ} \mathrm{C}$ for $1 \mathrm{~h}$.

seen in the graphic, the bonding strength of the basalt based as-coated coating was $19.34 \mathrm{MPa}$ that pointed as " 0 " time point in $x$ axis. Increasing the heat treatment time, the bond strength was decreased in the basalt based glass-ceramic coating. The highest bond strength value 18.10 MPa was obtained in the basalt based glass-ceramic controlled crystallization heat treatment at $800^{\circ} \mathrm{C}$ for $1 \mathrm{~h}$. Even if a heat treatment process was realized under argon atmosphere, it is probable that partial oxidation and also partially differences thermal expansion properties of the coating and substrate were caused bond strength decreasing according to heat treatment time increasing. It is probable that the bond strength of basalt based as-coated coating is higher than heat treated glass-ceramic coatings due to no oxidation by heat treatment.

\section{Summary}

In this study, the bond strength of the basalt based glass-ceramic coating was investigated. Basalt powder

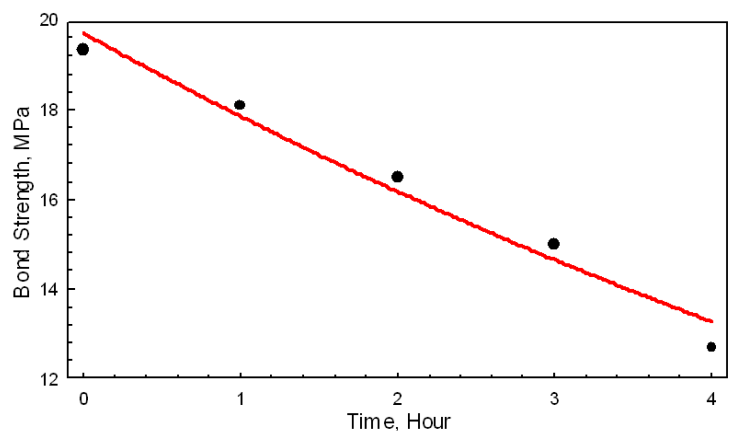

Fig. 5. Bonding strengths of glass-ceramic coating heat treated at $800{ }^{\circ} \mathrm{C}$ depending on heat treatment time.

was coated by APS coating technique on AISI 1040 steel that was pre-coated with $\mathrm{Ni}-5 \% \mathrm{Al}$ bond coat. Bonding strength of coatings was evaluated in accordance with the ASTM C-633 method. The amorphous glassy state was determined in basalt based as-coated coating. The coated samples were heat-treated at $800^{\circ} \mathrm{C}$ for $1-4 \mathrm{~h}$ for crystallization. The phases identified in the basalt based coating by XRD analysis are augite, Fe-diopside, anorthite and andesine in all treatment time. Basalt based glass-ceramic coatings include splat, porosity and un-melted particles which were the characteristic of plasma sprayed coatings. When the bonding strength of the basalt based as-coated coating was $19.34 \mathrm{MPa}$, the highest bond strength value $18.10 \mathrm{MPa}$ was measured in the heat treated glass-ceramic coatings at $800^{\circ} \mathrm{C}$ for $1 \mathrm{~h}$. Increasing the heat treatment time, the bond strength was decreased in the basalt based glass-ceramic coating.

\section{Acknowledgments}

The authors would like to express their gratitude to Sakarya University Engineering Faculty, and Prof. Fevzi Yllmaz for supporting this work. The authors are also grateful to Ebubekir Cebeci for helping coating process.

\section{References}

[1] C.C. Berndt, C.K. Lin, J. Adhesion Sci. Technol. 7, 1235 (1993).

[2] S. Yilmaz, M. Ipek, G.F. Celebi, C. Bindal, Vacuum 77, 315 (2005).

[3] G.W. Tyrell, The Principles of Petrology, Wiley, New York 1975.

[4] P.W. McMillan, Glass-Ceramics, 2nd ed., Academic Press, London 1979.

[5] S. Yilmaz, Ph.D. Thesis, Istanbul Technical University, 1997.

[6] S. Yilmaz, G. Bayrak, S. Sen, U. Sen, Mater. Des. 27, 1092 (2006).

[7] S. Yilmaz, G. Bayrak, Ceram. Int. 32, 441 (2006).

[8] G. Bayrak, Ph.D. Thesis, Sakarya University, 2009. 